DOI: https://doi.org/10.46630/bs.2.2019.01

UDK 316.44(497+510); 316.32(497)

Петьр-Емил Митев ${ }^{1}$

Софийския университет „Св. Климент Охридски“

София

България

\title{
ПЪТЯТ НАПРЕД. ГЛОБАЛНИЯТ КОНТЕКСТ
}

\section{Резюме}

В три водещи страни на съвременния свят се откроява специфична национална идея: САЩ, Русия и Китай. Американската мечта е притча за триумфираща индивидуалност. Нейна изходна точка е гражданското общество, неин център е успехът, критерий - материалният стандарт, контекст - масовата култура. Руската идея е разказ за триумфираща общност. Нейна изходна точка е държавата, критерий - религиозната духовност, централно понятие - съборността. Китайската мечта е нещо трето. Нейната изходна точка е държавата, с допълнението: държава, която е имала повече от хилядолетие зад гърба си по времето, когато Ромул и Рем са сучели от вълчицата. Нейната опорна точка не е църквата, а политическа партия. Духовността, за която пледира, се поддържа от традиционна светска система от правила и ценности. Но разликата с Руската идея е и в това, че Китайската мечта имплантира ключови моменти от Американската - успеха, материалния стандарт.

Няма Балканска мечта. Но и на Балканите хората желаят да живеят по-добре. Реализацията на Китайската мечта - по новия път на коприната, може и е логично да се срещне с балканските реалности. Срещата може и трябва да бъде взаимноизгодна.

Ключови думи: Китайска мечта, проект „Пояс и път”, Балкански страни.

\section{ГЛОБАЛНАТА ПРОБЛЕМНА СИТУАЦИЯ}

Живеем в необичайна преломна епоха. Не е първа в историята. Но е безпрецедентна по обхват и дълбочина. Видът Homo sapiens sapiens и респ. неговото общество се изправят пред нови по рода си предизвикателства - пред глобалните проблеми: екологично равновесие, ресурсно изчерпване, демографска асиметрия, социална пропаст между „златния милиард” и „гладуващия милиард”. И като връх на всичко - рисковете от ядрена война са, по оценка от $\mathrm{OOH}$, по-големи от всякога.

Според Арнолд Тойнби в историята на цивилизациите има определена закономерност. На определен период от развитието си те се сбльскват с предизвикателства, на които трябва да отговори техният елит. Ако съумее да отговори, цивилизацията продължава да се развива, ако не успее, тя загива; други цивилизации заемат нейното

1 petaremil@gmail.com 
място и продължават пътя напред.

Глобалните проблеми са комплексни и по-сложни в сравнение с традиционните. Изискват по-големи и най-важното - многостранни, дори всеобщи усилия. Следователно на дневен ред е потребност от качествено ново общуване, от нова по-висока степен на кооперативност. И залогът е необичайно висок - няма кой друг да поеме щафетата.

Сама по себе си обстановката е парадоксална. Правят се сериозни планове, за да се достигне до Марс, до друга планета. А самата Земя, нашата планета, е застрашена от разрушаване, навлиза в тежка екологична криза.

Проблемната ситуация актуализира една от основните тези на изтькнатия китайски революционер и бележит политически мислител Сун Ятсен: „Действието е лесно, познанието е трудно”. И не става дума толкова за масовия човек във всекидневието, който лекомислено хвърля пластмасова торбичка в планината или в морето. Става дума преди всичко за високото управленско равнище. Да, наистина е лесно да издадеш указ за санкции или санкционни мита, а е трудно да изчислиш всички икономически и политически последствия.

Илюстрация на това колко съвременно е заключението на Сун Ятсен съдържа последният (2018) доклад на Римския клуб, озаглавен: "Come on! Capitalism, short-termism, population and the distruction of the Planet”; „Хайде! Капитализъм, късогледство, население и разрушаване на планетата".

„Разрушение” е екологична диагноза. „Късогледство” - социална диагноза. Нито един от авторите не е комунист, но системният източник е фиксиран еднозначно: „капитализъм.” Поставянето на печалбата над всичко.

Разбира се, една страна може да се стреми да стане (отново) велика. Абсурдно е обаче да се допуска, че величието може да се изгражда за сметка на общочовешките интереси, които изискват, например, да се промени влиянието върху климата.

„Късогледство” е общо понятие за недалновидност. Но следва да се уточни: в редица важни случаи имаме „съзнателно затваряне на очите". И все пак, дори това не е източник на най-големите и фрапиращи рискове и опасности.

„Познанието е трудно” и защото пред него има едно съществено препятствие: лъжата. Българският философ Бернард Мунтян определи лъжата като глобален проблем, дори като глобален проблем Номер 1, защото неговото преодоляване -истината, само истината, цялата истина - е предпоставка за осмислянето и решаването на всички други глобални проблеми. Пост-истината и фалшивите новини са път към никъде.

В известен смисъл Пътят напред може да се формулира като Пътят към мъдростта. В случая това е понятие за онзи тип мислене, което се издига над специфичните користни интереси на отделните частни групи и е способно да разбере и отговори на предизвикателството на общото, на общочовешкото. В наши дни да 
се говори за „мъдър национализъм” е възможно само доколкото се разбира вграждането на националните и/или регионалните интереси в общочовешките. На съвременния етап Mъдростmа отговаря на общочовешката гледна точка. Тя противостои и на лъжата, и на постарото, обвързано с обикновено осмисляне на традицията разбиране за самата мъдрост.

Голяма крачка по пътя напред е, че се появи фундаментална формула на мъдростта: „Човечество на единната съдба”.

\section{ГЕОПОЛИТИЧЕСКАТА РЕАЛНОСТ}

Геополитическата история след Втората световна война дава поводи за размисъл и обобщения. Международните отношения преминаха през равновесно двублоково противостоене и неравновесен еднополюсен свят. Бомбардировките в Югославия (1999) поразиха моралната стойност на хегемонията, а войната в Ирак показа по найнагледен начин, че поддържането й руши международния правов ред и продуцира фалшиви новини и откровени лъжи. С укрепването на държавността (вкл. военната мощ) на Русия и особено с икономическия възход на Китай протича преход към многополюсен свят. Този процес не е завършил, но имаме достатъчно основания да смятаме, че е необратим. Глобалният свят е твърде сложен и противоречив, за да може да бъде дирижиран от един център и от една личност, дори ако разполага с най-голям икономически и военен потенциал. Този извод беше направен още през 90-те години не другаде, а в САЩ от водещ американски социолог - проф. Имануел Уолърстийн.

Проблемът обаче не се свежда до политическите аспекти, които означаваме като многополюсен свят. Става дума и за културния контекст, за преход към мултицивилизационен свят. Разбира се, и сега има различни цивилизации. Но има и концепции от рода на „сбльськ на цивилизациите”. А има и алтернатива на подобна перспектива, изразена ярко от президента Си Дзинпин. Ще си позволя да цитирам неговата гледна точка, защото я намирам за много съществена и актуална. Може да се изрази накратко с три думи: многоцветност, равноправност и инклузивност, включеност. Разнообразието на цивилизациите прави глобалния свят многоцветен, обогатява го. Равноправността е изискване за взаимно уважение. Инклузивността очертава път на развитие чрез размяна и взаимно опознаване, изучаване.

Във връзка с това ще маркирам един принципен и един практически въпрос.

Развитието на съвременно цивилизационно съзнание в Европа е обременено от наследството на специфично чувство за превъзходство, идеологизирано като европоцентризъм, еволюирал през XX в. до западноцентризъм. Постоянно слушаме да се изтькват „евроатлантическите ценности” като специфичен приоритет, без изобщо да се споменава, че има ценности на други цивилизации и най-важното - общочовешки ценности. 
Специално внимание заслужава сходството в развитието на цивилизациите. Симтоматично е например, че опитите да се осмисли историята, да се формулира философия на историята се появяват почти едновременно в класическата европейска античност и в Китай. Полибий в републиканския Рим и Сима Цян в Средното царство живеят в една и съща епоха (II - I в. пр.н.е.). Напълно самостоятелно и по различен начин те търсят зад описанието на събитията логиката в историческия процес. Прозренията на Сима Цян са запазили значението си не само като показател за достиженията на отдавна минала епоха, но и като повод за размисъл върху пътя напред.

В колосалното изследване ("Ши цзи") Сима Цян посочва три основни човешки качества, които изпъкват в хода на историята. (1) „Чжун” - прямодушие, искреност, правдивост; днес можем да прибавим още един синоним - прозрачност, и да акцентираме - отказ от лъжата. (2) „Цзин” - уважение, почтителност; в наши дни можем да прибавим и условието - равнопоставеност на цивилизациите. (3) „Вен” - културност, цивилизованост; актуализация: обществена откритост, инклузивност. Според Сима Цян акцентите върху едно или друго качество са водили до едностранчивост и трансформация. В съвременната епоха те стават необходими в своето единство и цялостност.

Практическият въпрос, който поставям, е недостатъчното познаване на китайската култура и цивилизация. В съвременна Европа, Балканите не правят изключение, значително повече се знае например за индийската култура и цивилизация. У нас издателство „Изток-Запад” развива впечатляваща дейност, но очевидно се нуждае от по-голяма подкрепа. Особено полезен според мене би бил превод на поне избрана част от цитирания труд на великия историк Сима Цян, който проследява историята на Китай от митовете за основаването му до I век пр.н.е. Доколкото ми е известно, не е превеждан на нито един от балканските езици. Българските изследователи ползват изданието на руски език в 9 тома, започнато в СССР и завършено в Руската федерация.

Китай и Индия възстановяват своя суверенитет през XX в. и влизат в модернизацията по различни пътища. Добре известен е Махатма Ганди и идеята му за ненасилието. За да се разбере дълбочината и основателността на Китайската революция, твърде важно е да се направят достъпни произведенията на Сун Ятсен, първия президент на Китайската република.

И последен акцент. Широка международна популярност има „Изкуството на войната”, написана вдъхновено от Сун Дзъ преди 25 века. Идва ми на ум идеята за един сборник на тема „Изкуството на мира" с избрани речи и статии на президента Си Дзинпин (в ОOH, ЮНЕСКО, на различни форуми). Това е толкова по-важно, като се имат предвид фалшивите новини: активността на Китай среща противодействие - внушения и подозрения, разпространявани от тинк-танкове и либерални медии. 
Разбира се, за цивилизационния диалог ще бъде важно да се появят в Китай произведения на водещи балкански автори - класически и съвременни. Културното взаимодействие създава предпоставките за оптимално решаване на геополитическите въпроси.

\section{СЯОКАН И ПО-НАГОРЕ. КИТАЙСКАТА МЕЧТА}

Китайската народна република си поставя дългосрочни цели, но рамкирани от конкретни срокове. Избрани са символни дати: 2021 година - стогодишнината от създаването на ККП, и 2049 година стогодишнината от основаването на КНР. Към първата дата трябва да бъде постигнато сяокан общество, а към втората - да завърши програмата за национално възраждане.

Сяокан е понятие, заимствано от китайската културна традиция, от конфуцианството, и актуализирано от Дън Сяопин. Обикновено се превежда като „общество на базовото благосъстояние”. Но китайският термин има по-богато съдържание, което обхваща не само материалната, а и духовната страна в обществения и личния живот, хармонията между тях.

Базово благосъстояние и по-нататьшен напредък в три аспекта: просперираща държава, развитие на нацията, благоденствие на хората. Това не е утопия. Не е небе. Това е земя. Това е рационална цел.

През второто десетилетие на XXI век Китай тръгва към своето бъдеще с респектиращи постижения. Свикнали сме да мислим за Китай като страната с най-голямо население. Трябва да се коригираме това е страната с най-много студенти: в китайските университети учат повече от 30 милиона студенти. А всяка година повече от 300 хиляди млади китайци отиват да учат в чужбина. Това става по време, когато светьт върви към „общество на знанието”. Китай е страната с наймного потребители и същевременно е най-голям стокопроизводител. Роди се дори анекдот: „Господ е създал небето и земята, а всичко друго са направили китайците".

Разбира се, политическата рационалност се определя не само от целта, но и от средствата, от пътищата за постигането й.

Централно понятие в китайската практика е реформа. В Китай реформата започнатогава, когато у нас всеоще владееше революционен дух. Добре известно е, че тъкмо реформата, която включи пазарния принцип и отварянето към света, преобрази китайското общество.

Знаменитият западен социолог Макс Вебер е автор на книга, смятана за научен шедьовър - „Протестантската етика и духът на капитализма”. Пред днешните социолози е нов феномен „Конфуцианската етика и духът на пазарния социализъм”.

За онези, които се интересуват от историята на политическата мисъл, повод за размисъл и анализи ще бъде еволюцията на реалния социализъм от най-голямата страна (по пространство) до най-старата (по време); от свръхцел на социално инженерство до реалистична перспектива на балансиран икономически и социален напредък; от 
рязка конфронтация на „обсадено общество” до интегрална част от световната икономика.

Нито една източноевропейска страна, включително Русия, не ce е опирала на своята традиция така както виждаме това в днешен Китай. Революцията неизбежно включва прекъсване, пречупване на традиции. Китай не само не направи изключение, но даде и най-яркия пример. Преди почти половин век светът беше изненадан и озадачен от опит чрез радикално отрицание да се скъса с традицията и статуквото и да се извърши скок в ново културно и политическо пространство. Резултатите са известни. Сега националното възраждане се опира плътно на управленската и културната, на цивилизационната традиция на Стар Китай и заедно с това - на политическия опит, поуките и държавническата мъдрост, натрупани в развитието на Нов Китай.

Българският път през годините, през които сами започнахме реформи, беше белязан от острата конфронтация на лявото и дясното. Книгата на президента Си Дзинпин „Китайската мечта” провокира леви и десни прочити. В отговор на идеологическото любопитство ще изтъкна, че понятията „ляво” и „дясно” липсват в книгата. Има обаче разграничения, които е логично да се измерят с такъв мащаб. „Ние няма да се върнем по стария път с неговата затвореност и закостенялост, както и няма да тръгнем по порочния път на отказ от нашите идеи.” „Старият път” е левичарският догматизъм. „Порочният път” е дясната либерализация. Отказът от пренасянето на западната система на либерална демокрация в Китай беше обоснован от Дън Сяопин със същата последователност, с която бяха осъществени реформите и отварянето към света. Основен проблем на политическата система в страна с население, надхвърлящо един милиард, с различни региони и етноси, е стабилността. Пазарното развитие неизбежно я разклаща, поставя я под выпрос. Противотежест е еднопартийната политическа система и нейното вътрешно развитие. Какво развитие? Легитимността на ръководната роля не се извежда от идеологическата правота, а се доказва, като се носи щафетата на цивилизационния напредък. Идеологическият мандат сам по себе си съдържа и произвежда догматизъм: важното е „котката да е бяла”. Цивилизационният мандат изисква прагматизъм: важното е „котката да лови мишки, без значение дали е бяла или черна”. Цивилизационният мандат предполага и различни мнения, и единодействие. Само в такъв случай щафетата няма да бъде изпусната. В книгата изрично се посочва: „Трябва да разберем, че е напълно възможно хората от различни места, от различни прослойки, от различни сфери по различни въпроси да имат различни разбирания и начин на мислене."

По-нататъшното развитие на политическата система е определено от Си Дзинпин като „демократизация”. Очевидно конкретните стъпки ще бъдат уточнявани. Ще отбележа един първостепенен по значението си управленски факт, който илюстрира такива стъпки. Нито една управляваща комунистическа партия не можа да реши въпроса с персонализацията на властовия връх. Нито една, с изключение на китайската. Смяната на поколения ръководители 
беше превърната в регламентирано правило. Самият Си Дзинпин е водещият представител на петото поколение китайски ръководители.

Възходът на Китай може да внесе тревоги в свят, който все

още не е приел устойчив многополюсен ред. „Китайската мечта” формулирана и обоснована от китайския президент внася спокойствие. Не само и не толкова с декларираните отново принципи на мирното съвместно съществуване, колкото с основното си съдържание. За да се реализира китайската мечта, е нужен мир. Мир в глобалния свят. Стабилността на света се подчертава чрез отношенията между Китай и САЩ. Несъмнено това отговаря на глобалната реалност и съдържа известен парадокс. Съединените щати са сравнително млада държава, на малко повече от двеста години. Китай е най-старата. Това е важна част от спецификата на формиращия се нов глобален дуализъм, на новата $\Gamma-2$.

В три водещи страни на съвременния свят се откроява специфична национална идея: САЩ, Русия и Китай. Тези идеи не се изключват. Всяка се разполага в собствена ниша, движи се по собствена орбита. Сравнението има културологичен смисъл, доколкото откроява diferentia specifica на всяка от тях. Американската мечта е притча за триумфираща индивидуалност. Нейна изходна точка е гражданското общество, неин център е успехът, критерий - материалният стандарт, контекст - масовата култура. Руската идея е разказ за триумфираща общност, базовата формулировка е: самодържавие, православие, народност. Нейна изходна точка е държавата, критерий - религиозната духовност, поддържана от църквата, централно понятие-съборността.

Китайската мечта е нещо трето. Нейната изходна точка е държавата, с допълнението: държава, която е имала повече от хилядолетие зад гърба си по времето, когато Ромул и Рем са сучели от вълчицата. Нейната опорна точка не е църквата, а политическа партия, с допълнението: партия, която има повече членове от населението на най-голямата страна в ЕС. Духовността, за която пледира, се поддържа от традиционна светска система от правила и ценности. Но разликата е не само в съдържанието на сходни елементи в Руската идея и Китайската мечта. Разликата е и в това, че Китайската мечта имплантира ключови моменти от Американската - успеха, материалния стандарт.

Ще успее ли Китайската мечта? На този въпрос ще отговори историята. До 2049 г. има още доста време, толкова вода ще изтече, че е прекалено рисково, за мнозина просто неподходящо, да се каже „поживём, увидим”. Междувременно внимателният прочит на книгата-послание на председателя Си Дзинпин подсказва: ще печелят - и в Китай, и извън него - онези, които заложат на успеха.

\section{ПРОЕКТЬТ „ПОЯС И ПЪТ” И БАЛКАНСКИТЕ РЕАЛНОСТИ}

Динамиката в международния живот засяга преди всичко сложните отношения в ключовия геополитически триъгълник: САЩКитай-Русия. Европа има потенциал за самостоятелна и равностойна 
роля, но й липсва държавна субектност. В стратегически план Европа

е партньор на САЩ, част от „колективния Запад”. В хода на текущия политически процес заема адхок позиции, близки до Русия и Китай по важни въпроси - ядрената сделка с Иран, Парижкото споразумение за климата, търговския протекционизъм и свободата на търговията. Последните въпроси имат стратегически характер и допринасят особено за сближаването на ЕС и Китай. Русия се стреми да утвърди и разшири своята енергийна връзка с Европа. Китай планира и реализира инфраструктурен мегапроект „Пояс и път”. И в двата случая става дума за интеграцията на Евразия. Американската стратегия е насочена, обратно, към отслабване и/или прекъсване на връзките в пространството от европейския Запад до руския и китайския Изток.

Глобалната геоикономическа инициатива е в ръцете на Китай. Вторият международен форум на високо равнище по проекта „Пояс и път" показа това много убедително. На територията на мегапроекта живее $63 \%$ от населението на света, проектната стойност е 21 трилиона щатски долара.

САЩ не могат да се похвалят с подобна конструктивна инициатива. Бившиятпрезидент БаракОбаманасочиусилиятасикъммащабензамисъл от друг тип (транстихоокеанско и трансатлантическо споразумения за свободна тьрговия и партньорство), които подават топката на „невидимата ръка на пазара", т.е. на видимите Транснационални корпорации (ТНК). След като президентьт Доналд Тръмп смени курса - от „глобализация” към „патриотизъм”, и двата проекта бяха закрити. Най-значими инициативи на САЩ през последните две години са санкционните мита, които водят до взаимна загуба.

Проектът „Пояс и път” прокарва множество инфраструктурни коридори, които създават връзки между далекоизточния и западния край на Евразия. Последствията ще бъдат не само икономически, но и геополитически. Оттук е заинтересоваността да се спъва проектът.

Един от коридорите логично достига до Балканската врата на Европа.

Балканските страни имат значително по-кратка от китайската, но достатъчно драматична история. Обусловена е от тяхното географско, а оттам и геополитическо място - кръстопът между Европа и Азия. През Балканите са минавали силово и в двете посоки. От Запад на Изток - от рицарите на Четвъртия кръстоносен поход до немската армия през Втората световна война. От Изток на Запад - османските турци, които включват целия полуостров в своята империя и стигат до Виена. На територията на Балканите се водят руско-турски войни. Тук се кръстосват интересите на „великите сили” от Западна Европа и Русия. Проекция на това противостоене е ориентацията на балканските политически елити като „,-фили” или на някоя западна страна, или на Русия.

След 1989 г. социалните системи в балканските страни стават сходни и влизат в категорията на периферния капитализьм, анализиран задълбочено от проф. Любиша Митрович. 
Проличават различията в развитието на бившите социалистически страни в региона и страните от Централна Европа. Американският социолог от унгарски произход проф. Иван Селени ги характеризира като различие между неолибералния и патерналистичния варианти на посткомунистическо развитие. Съществената разлика е директно свързана с външен фактор. На Полша външния дълг е опростен, на България - дори не е разсрочен. В Унгария и Чешката република се изсипва „златен дъжд” от инвестиции, в Югославия - бомби. В крайна сметка балканските елити се ориентираха към членство в ЕС, някои прекрачиха прага на Съюза, други - Западните Балкани, са в „чакалнята”. Кохезионната политика на ЕС дава определен шанс за развитие на страните от периферния капитализъм. Но този шанс не е достатъчен, от друга страна се оспорва и крайното решение все още предстои. Възможностите, които дава проектът „Пояс и път”, придобиват твърде съществено значение за всяка отделна страна и за региона като цяло, за да се придвижи от периферията към центъра в социално-икономически план.

През 2001 г. беше основан „Балкански политически клуб” по идея на д-р Желю Желев, първият демократично избран президент на България. В него влязоха редица известни балкански политици. Основна цел, която виждаше д-р Желев, беше да се съдейства за развитието на балканската инфраструктура, на връзките между балканските страни. Активността на клуба западна, но целта остава в сила.

Проектът „Пояс и път” включва модерна ж.П. линия БелградБудапеща. Но може да се погледне по-широко. Да, можем да си представим един съвременен „Ориент експрес”, свръхскоростен влак Истанбул-София-Белград-Будапеща-Виена-Париж-Лондон. В същото време няма дори традиционна ж.п. връзка между София и Скопие. Или магистрала София-Ниш...

\section{ЗАКЛЮЧЕНИЕ}

Китайската политическа история в най-ново време е много поучителна и насочва към предпоставките за успешно движение по „Пътя напред”. От една страна, това е революционният оптимизъм. В 1945 г. председателят Мао актуализира древната легенда „Юй Гун премести планината", легенда за стареца, чиято вяра в своето начинание е била толкова силна, че е станало чудо. И от друга страна - строителният прагматизъм на Дьн Сяопин. Оптимизмът е вграден в основите на Китайската народна република, но развитието на страната показа и рисковете, когато не е достатъчно обоснован. Прагматизмът е необходимата противотежест. Виждаме и двете страни - и революционният оптимизъм, и строителният прагматизъм, въпльтени в идеите на президента Си Дзинпин за социализъм с китайска специфика, виждаме ги в Китайската мечта.

Разбира се, и на Балканите хората желаят да живеят по-добре. Но няма Балканска мечта. Китайската мечта - по новия път на коприната, 
може и е логично да се срещне с балканските реалности. Срещата може и трябва да бъде взаимноизгодна.

\section{БИБЛИОГРАФИЯ}

Вайцзекер, Ернст и Андерс Вийкман. Хайде! Капитализъм, късогледство, население и разрушаване на планетата. Доклад на Римския клуб. София: Изд. Книжен тигър, 2018.

Дън Сяопин. Китайският път - реформи и стабилност. Избрано. Съст. П.-Е. Митев. София: ЛИК.

Конрад, Н. И. 1972. Запад и Восток. Статьи. Москва: Наука, 1999.

Мао Цзэ-дун. Избранные произведения. Т. 4. Москва: Изд. иностранной литературы, 1953.

Митрович, Любиша. Преходът към периферен капитализъм. София: Изд. „Изток-Запад”, 2010.

Мунтян, Бернард. Накъде отиваш Hото sapiens? Към свят на постлъжата и мъдростта или...? София: изд. „Захарий Стоянов /в прозводство/, 2019.

Полибий. Всеобщзая история. Т. 1 - 3. СПб: Ювента, 1994-1995.

Политическата ситуащия. Институт по социология „Иван Хаджийски”, Април. 2019.

Райчев, Андрей. Време и всичко. Пловдив: Жанет45, 2017.

Селени, Иван. Бедност и сочиална структура в преходните общества. Първото десетилетие на посткомунизма. София: Изд. „ИзтокЗапад", 2013.

Си Дзинпин. О государственном управлении. Пекин: Изд. литературы на иностранных языках, 2014.

Си Дзинпин. Китайската мечта. Превод на Е. Хайн и Т. Радев. София: Изд. „Изток - Запад”, 2015.

Сунь Ятсен. Избранные произведения. Москва: Наука, 1985.

Сыма Цянь. Исторические записки. В 9 томов. Москва: Наука, 19722010.

Wallerstein, Immanuel. The End of the World as We Know It: Social Science for the Twenty-first Century. Minneapolis: University of Minnesota Press, 1999. 


\section{Summary}

Each of the three leading states in our modern world, USA, Russia and China, cherishes its specific national idea. The American dream is an alias for the idea of triumphant individuality. Its starting point is civil society, its essence, success, its standard, material prosperity, its context, mass culture. The Russian idea translates into a victorious community, with the state as a starting point, religious spirituality as its standard and convocation (соборность) as its pivotal concept. Chinese dream is once again different for, while confirming that state is the starting point, it also adds longevity to it, since at the time The She-Wolf of Rome was nurturing Romulus and Remus there had been a Chinese state for over one thousand years. Consequently, Chinese dream has as its basis a political party, rather than a religious temple; its spirituality builds on the traditional lay system of rules and values. In addition, it complements the Russian idea by implanting into it key aspects of the American dream, namely, success and prosperity.

There is no Balkan dream. Yet in the Balkans, people, too, dream of a better life. The materialisation of the Chinese dream could logically so - encounter Balkan reality along its new Silk Route. This meeting can and must be, mutually advantageous.

Key words: China dream, Belt and road initiative, Balkan countries 